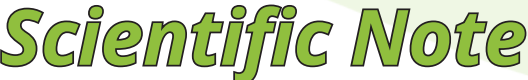

\section{Epicauta vittata (Fabricius): occurrence in tomato plant and weeds in the State of Rondônia}

\author{
Claudemir Schwanz Turcato ${ }^{\bowtie}$, Freddy Melo Toledo, Emanoel Pereira Sampaio, Cleiton Dias Alves, \\ Vando Miossi Rondelli, Jairo Rafael Machado Dias \& Fábio Régis de Souza
}

Departamento de Agronomia, Universidade Federal de Rondônia, UNIR.

\section{EntomoBrasilis 13: e0861 (2020)}

Edited by:

Marliton Rocha Barreto

Article History:

Received: 11.vi.2019

Accepted: 27.xii.2019

Published: 22.iv.2020

$\bowtie$ Corresponding author:

Claudemir Schwanz Turcato

७ claudemirst.1994@gmail.com

(1) No ORCID record

Funding agencies:

$\&$ Without funding declared

\begin{abstract}
The tomato (Solanum lycopersicum L.) plant stands out for being a species cultivated throughout the national territory, being the most important vegetable in Brazil, from the socioeconomic point of view. However, it has been one of the crops most affected by phytosanitary problems. For example, there are the pest insects of the genus Epicauta (Coleoptera: Meloidae). Thus, the objective of this study was to record the occurrence of a pest insect (beetle) harming vegetative growth and productive performance in the fresh-market tomato crop and feeding on weeds. The tomato plants were found on "jurubeba" (Solanum paniculatum L.) rootstock, spaced $1.0 \mathrm{~m} \times 0.5 \mathrm{~m}$, grown in the municipality of Rolim de Moura, Rondônia state. The insect-pest (beetle) was identified as Epicauta vittata (Fabricius). It was observed that the damages caused by the larvae occurred in the main stem of the tomato, only above the grafting site, causing boring, however no damage was observed in the rootstock ("jurubeba"). Adult insects caused defoliation in both tomato plant and joyweed (Alternanthera tenella Colla), slender amaranth (Amaranthus viridis L.), "trapoeraba" (Commelina benghalensis L.) and morning glory (Ipomoea purpurea [L.]). High population of E. vittata causes severe damages to tomato, damaging the vegetative growth and productive performance of the crop, however does not affect the root system when grafted with "jurubeba" (S. paniculatu). Epicauta vittata in the adult phase is fed alternately of weeds.
\end{abstract}

Keywords: Alternanthera tenella; Amaranthus viridis; Commelina benghalensis; Ipomoea purpurea; striped blister beetle. $\square$ Domatoes are among the most cultivated vegetables in Brazil, being cultivated throughout the national territory, thus, they deserve to be highlighted both from an economic and social point of view. It is cultivated in 57,717 ha, with a production of 4,004,991 $\mathrm{kg}$, presenting an average yield of 69,471 $\mathrm{kg} \mathrm{ha}^{-1}$ (IBGE 2019).

Of the total production, $70 \%$ is destined for the market for in natura consumption (table tomatoes) and the rest for industry. For in natura market, it is usually cultivated in a tutored manner, with emphasis on semi-staked staking. When the fruit is destined for the industry, it is commonly used an undergrowth cultivation, without any type of conduction (MAKISHIMA \& MeLO 2009).

Despite the success of tomato farming in Brazil, it is one of the vegetables that has been most affected by phytosanitary problems, among which the presence of pest insects that cause damage to the crop throughout the cycle stands out. In this sense, Epicauta spp. (Coleoptera: Meloidae), popularly known as striped blister beetle, it is an insect extremely harmful to the species of the family of the solanaceae, being able to feed itself in fruits and leaves, in a destructive way (SALAS et al. 1999; CAPINERA 2003).

The Meloidae family includes more than 2,500 species in the world (KINNEY et al. 1998), some of which constitute agricultural pests, especially plants of the families Leguminosae, Solanaceae, Amaranthaceae and Compositae. Adults have long legs, a fully exposed head, a pronotum narrower at the extremity, a navicular body and strongly sclerotized. Most adults eat only floral parts, however, some, in particular Epicauta spp., also feed on leaves (Selander \& Fasulo 2000).

Species of the genus Epicauta are often described as pests of different cultures in Brazil, causing considerable damage (Lourenção et al. 1985; Bolça Junior et al. 2007; Moura et al. 2014; CARMo et al. 2019). Epicauta atomaria (Germar), known as striped blister beetle, is a very common species, which feeds on leaves, causing numerous holes (Gallo et al. 2002). Additionally, Epicauta vittata (Fabricius) is native to the United States of America and has been reported to damage several solanaceae, such as peppers, tomatoes, eggplants and potatoes (CAPINERA 2003; CARMo et al. 2019). Thus, the objective was to record the occurrence of this insect pest (striped blister beetle) impairing vegetative growth and productive performance in the cultivation of table tomatoes and feeding on weeds.

Larvae, pupae and adults of insect-pest (striped blister beetle) were collected, causing damage to the main stem and promoting defoliation in the tomato [Solanum lycopersicum L. (Solanaceae)], Cv. Fascínio, and concomitantly feeding on weeds joyweed [Alternanthera tenella Colla (Amaranthaceae)], slender amaranth [Amaranthus viridis L. (Amaranthaceae)], "trapoeraba" [Commelina benghalensis L. (Commelinaceae)] and morning glory [Ipomoea purpurea (L.) (Convolvulaceae)]. 
The tomato plants were on rootstock of "jurubeba" [Solanum paniculatum L. (Solanaceae)], conducted in a semi-stacked system, with spacing of $1.0 \mathrm{~m} \times 0.5 \mathrm{~m}$, making a population of 20,000 plants ha $^{-1}$, being grown on the experimental campus from the Federal University of Rondônia (Universidade Federal de Rondônia), in the municipality of Rolim de Moura, State of Rondônia ( $\left.11^{\circ} 34^{\prime} 57^{\prime \prime} \mathrm{S}, 61^{\circ} 46^{\prime} 21^{\prime \prime} \mathrm{W}\right)$, from November 11, 2018 to December 06, 2018.

The larvae, pupa and adult phases of the insect pest and the damage were recorded in the tomato crop. In addition, the presence of the adult was recorded, causing defoliation in the aerial part of the weeds joyweed, slender amaranth, "trapoeraba" and morning glory. The photographic record was performed with a Samgung Galaxy J7 Prime cell phone with a 13 megapixel digital camera.

To control the insect pest, the contact and ingestion insecticide Deltamethrin, from the chemical group of the Pyrethroids (Decis $25 \mathrm{EC}^{\circledR}$ ), was used in the concentration of $30 \mathrm{~mL} 100 \mathrm{~L}^{-1}$ of water.

The insect pest observed in the area was identified as $\mathrm{E}$. vittata. The egg phase of this species lasts between 10 and 16 days and the pupal period from 9 to 13 days (CAPINERA 2003). The specimens of $E$. vittata collected on the tomato measure between 9 and $17 \mathrm{~mm}$ in length, have brown heads and pronotum and dark elytra, with white edges and a white longitudinal line (Figure 1), as described by (CAPINERA 2003).

Epicauta vittata is native to the United States, occurring in many states, and is also reported in Canada (CAPINERA 2003). The only occurrence of this species in Brazil was in Rondônia, in 2017 (CARMo et al. 2019). There are records of E. vittata in several cultures, such as: solanaceous, brassicas, cucurbits, carrot, bean, soybean, beet, corn and sweet potato (CAPINERA 2003; CARMo et al. 2019).

The initial damage caused by $E$. vittata was observed at 30 days after transplanting, persisting until the end of the culture cycle. In the tomato, the larvae pierced the main stem, causing blackening followed by necrosis of the conducting vessels (Figure 1: A-C). This damage caused in the xylem, probably limited the transport of water and nutrients in the plant and the redistribution of carbohydrates by phloem, which initially promoted symptoms of wilt and nutritional imbalance in damaged plants.

Additionally, it was noted that damage to the conductive vessels has always occurred above the grafting site, leading to reduced growth and development of the tomato (graft). It is noteworthy that the rootstock of "jurubeba" was not damaged below the grafting site (Figure 1: A-D).

In the hottest hours, adults took shelter in the soil and in the axillae of tomato plants. The larvae were already lodged inside the main stem. The adult insect caused the defoliation of the tomato (Figure 1: E and F), reducing the leaf area, as observed by CARMO et al. (2019) in the pepper and eggplant culture.

Defoliation caused by adults of $E$. vittata was also found in the weed species $A$. tenella, $A$. viridis, $C$. benghalensis e I. purpurea (Figure 2). According to CAPINERA (2003), Amaranthus spp. it is highly preferred by adults. Thus, $E$. vittata is a polyphagous species. Therefore, strict cultural management of alternative hosts is required, since the presence of $E$. vittata in areas with tomato cultivation can exponentially increase the pressure of this insect, becoming a pest, since the tomato seems to properly feed E. vittata, favoring its rapid multiplication, which can make commercial activity unfeasible.

The chemical control of $E$. vittata adults was done with the insecticide Deltametrina. On the other hand, there was no death of pupae and larvae, since in the young stage, insects were found inside the main stem of the tomato, preventing the action of the insecticide, since its mode of action is contact and ingestion. Thus, a systemic insecticide would possibly control the larvae. Thus, for effective control of $E$. vittata, in addition to chemical control, it was necessary to manually pluck the damaged plants, removing them from the field. However, it is necessary to evaluate seasonality in weeds and natural enemies of this insect pest, in order to contribute to integrated management.

High infestation of $E$. vittata impairs the vegetative growth and productive performance of the tomato. Because it is a polyphagous insect, $E$. vittata can feed on the adult stage of A. tenella, A. viridis, C. benghalensis e I. purpurea. The young phases of $E$. vittata do not feed on S. paniculatum when used as rootstock for tomato.
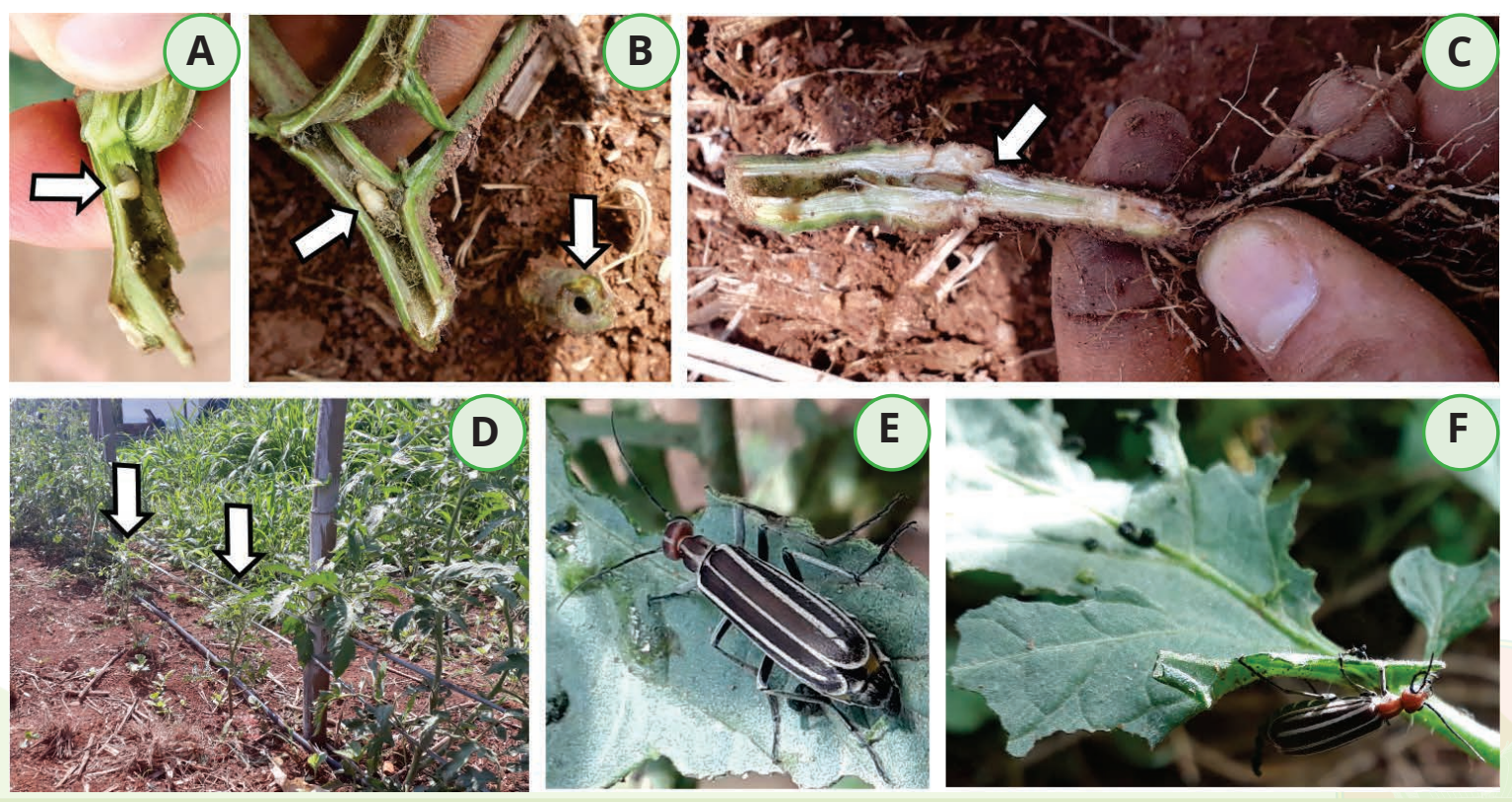

Figure 1. Damage caused by Epicauta vittata in tomato in the State of Rondônia. (A) Larva feeding on the main stem. (B) Pupa in the main stem pierced and cross-sectional view of the main stem Pupa in the main stem pierced. (C) Gallery formation, just above the rootstock of "jurubeba". (D) Plants with reduced development due to damage to the main stem. (E and F) Adult of E. vittata causing defoliation in tomato (Photos: Turcato, CS). 


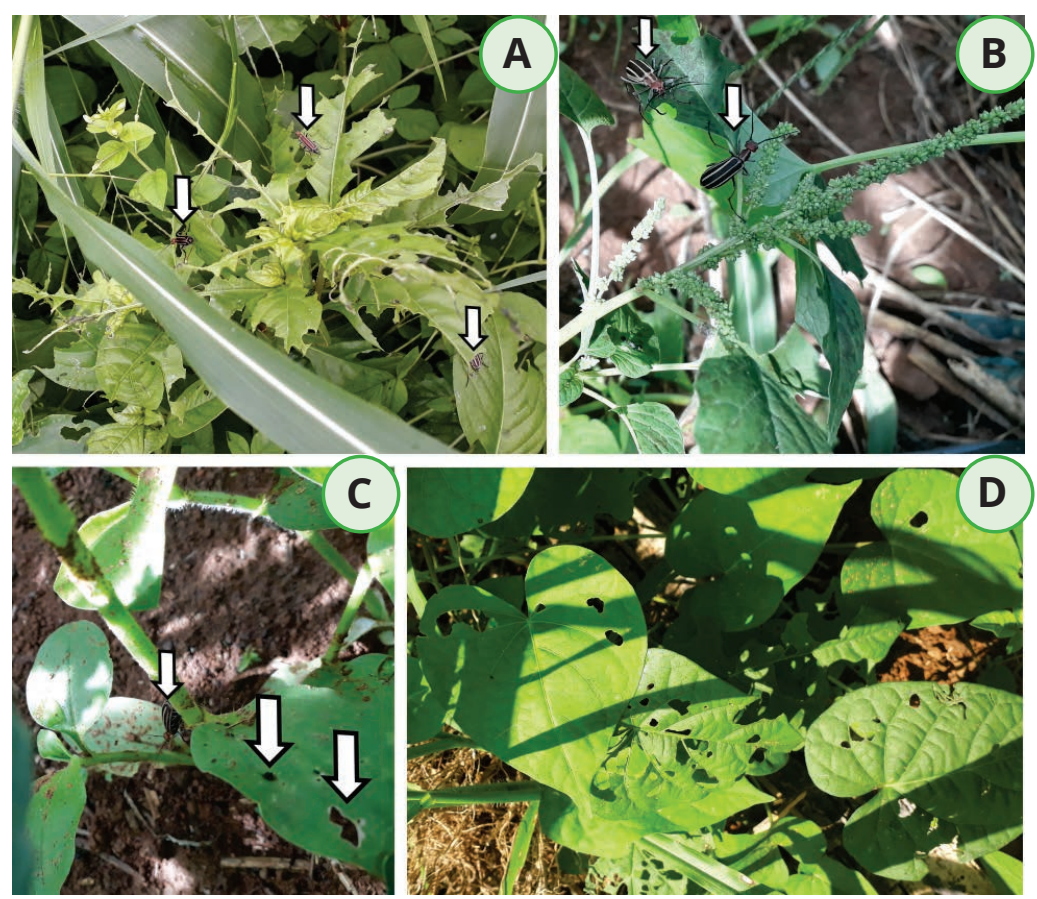

Figure 2. Weed defoliation caused by Epicauta vittata in the State of Rondônia. Adults and damage (defoliation) in joyweed, Alternanthera tenella (A) and slender amaranth, Amaranthus viridis (B). The smaller arrow shows the adult and the larger the damage (defoliation) in "trapoeraba", Commelina benghalensis (C). Damage (defoliation) in morning glory, Ipomoea purpurea (D) (Photos: Turcato, CS).

\section{REFERENCES}

Boiça Junior, AL, JZ Baptista, JC de Oliveira \& FG de Jesus, 2007. Atratividade e preferência alimentar de Epicauta atomaria (Ger.) em algumas espécies de maracujá. Revista Brasileira de Fruticultura, 29: 471-476. DOI: https://doi. org/10.1590/S0100-29452007000300013

Capinera, JL, 2003. Striped Blister Beetle, Epicauta vittata (Fabricius) (Coleoptera: Meloidae). University of Florida Ifas Extension. Available in: <http://edis.ifas.ufl.edu/ pdffiles/in/in55600.pdf>. [Accessed on: 04.ii.2019].

Carmo, MC; VM Rondelli, AG Ferreira \& D Pratissoli, 2019. Epicauta vittata (Fabricius, 1775) (Coleoptera: Meloidae): ocorrência em cultivo de pimentão e berinjela no Estado de Rondônia. Scientia Amazonia, 8: 6-10.

Gallo, D; O Nakano, S Silveira Neto, RPL Carvalho, GC Batista, E Berti Filho, JRP Parra, RA Zucchi, SB Alves, JD Vendramim, LC Marchini, JRS Lopes \& C Omoto, 2002. Entomologia Agrícola. Piracicaba, FEALQ.

IBGE (Instituto Brasileiro de Geografia e Estatística). Levantamento sistemático da produção agrícola setembro 2019. IBGE. Available in: <https://sidra.ibge. gov.br/home/lspa/brasil>. [Accessed on: 04.xi.2019].

Kinney, KK, FB Peairs \& AM Swinker, 1998. Blister Beetles in Forage Crops. Colorado State University, U.S. Department of Agriculture and Colorado State University Extension Service. Available in: <https://extension.colostate. edu/docs/pubs/insect/05524.pdf>. [Accessed on:

\section{7.v.2019].}

Lourenção, AL, VP de Oliveira \& MAM Boaventura, 1985. Danos de adultos de Epicauta atomaria (Germar, 1821) em plantas de farinha-seca. Bragantia, 44: 437-440. DOI: https://doi.org/10.1590/s0006-87051985000100040

Makishima, N \& F Melho, 2009. O rei das hortaliças. Grupo Cultivar. Available in: <https://www.grupocultivar. com.br/ativemanager/uploads/arquivos/artigos/ hf29_rei.pdf> [Accessed on: 17.v.2019].

Moura, AP de, M Michereff Filho, JA Guimarães, GB Amaro \& RS de Liz, 2014. Manejo integrado de pragas do tomateiro para o processamento industrial. Brasília: Embrapa Hortaliças (Circular Técnica, 129).

Salas, FJS, MM Barradas \& JRP Parra, 1999. Tentativas de transmissão de um isolado do vírus do mosaico severo do caupi (CpSMV-SP) por artrópodos em laboratório. Scientia Agrícola, 56: 413-420. DOI: https://doi.org/10.1590/ s0103-90161999000200022

Selander, RB \& TR Fasulo, 2000. Blister Beetles (Insecta: Coleoptera: Meloidae). Florida: Institute of Food and Agricultural Sciences, University of Florida (Document: EENY166-originally published as: DPI Entomology Circular, 268).

\section{Suggestion citation:}

Turcato, CS, FM Toledo, EP Sampaio, CD Alves, VM Rondelli, JRM Dias \& $F R$ de Souza, 2020. Epicauta vittata (Fabricius): occurrence in tomato plant and weeds in the State of Rondônia. EntomoBrasilis, 13: e0861. Available in: doi: 10.12741/ebrasilis.v13.e0861
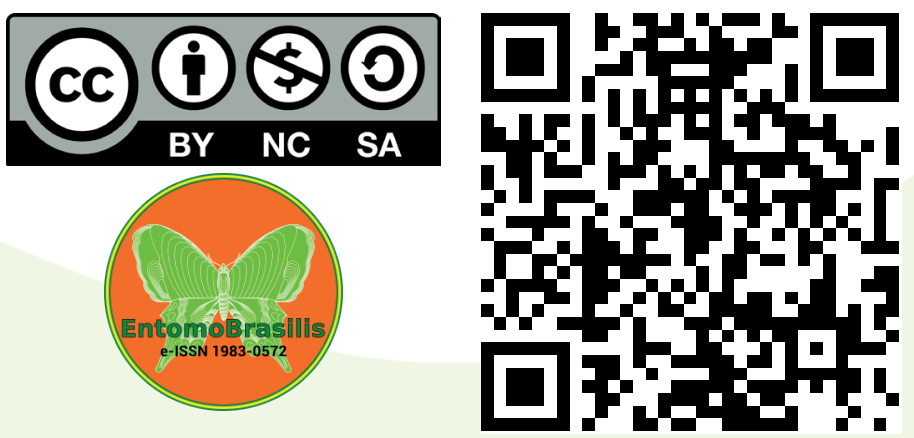